\title{
Universities and standardization instruments: the willingness to put an end to the organized anarchy
}

\author{
Croché, Sarah ${ }^{\mathrm{a}}$; Charlier, Jean-Émile ${ }^{\mathrm{b}}$
}

${ }^{a}$ UFR SHS, University Picardie Jules Verne, Amiens, France, ${ }^{b}$ Department ESPO, Catholic University of Louvain, Belgium.

\begin{abstract}
Many sociologists have for a long time based their research on the work published in the 1970s, in which universities were regarded as organisations that operate in a particular way. They were approximated to "organised anarchies" or to "loosely coupled systemswhich were considered host to "unclear technologies.This article call into question these concepts and confront them with the evolution of the piloting way of contemporary establishments of European higher education. The empirical material for this paper comes from the analysis of texts and reforms initiated in European universities. The paper will show the effects of standardization instruments on academic profession and how these instruments (and notably the learning outcomes approach) transform each segment of the university and generate a deep interdependence between all of them.
\end{abstract}

Keywords: Standardization instruments; organized anarchy; universities; academic profession 


\section{Introduction}

Many sociologists have for a long time based their research on the work published in the 1970s, in which universities were regarded as organisations that operate in a particular way. They were approximated to "organised anarchies" (Cohen et al., 1972) or to "loosely coupled systems" (Weick, 1976 ; Orton \& Weick, 1990) which were considered host to "unclear technologies" (Cohen \& March, 1974). This article call into question these concepts and confront them with the evolution of the piloting way of contemporary establishments of higher education.

The empirical material for this paper comes from the analysis of texts (published between 1998 and 2016 by the European Commission, the OECD and the members of the piloting group of the Bologna Process) and reforms initiated in European universities (especially since 1998 with the progressive introduction of the quality assurance mechanisms and the learning outcomes approach in Belgium, Denmark, France and United Kingdom). The paper is divided in three parts. The first concern the different instruments (such as ECTS and diploma supplement) developed by international organisations and their integration in an apparatus (in Foucault's sense) of standardization of higher education. The second analyses the effects of these instruments and of the apparatus on academic profession and inscribes the article in the whole of works (see for example Derouet and Normand, 2012; Evans and Nixon, 2015; Lucas, 2014; Normand, 2015) examining the nature and extent of the changes experienced by the academic in their teaching profession in recent years. The third studies how these instruments (and notably the learning outcomes approach) transform each segment of the university and generate a deep interdependence between all of them.

\section{Inter-connected instruments in European higher education}

Since fifteen years, some "public policy instruments" (in the sense of Lascoumes and Le Galès) were installed in higher education in the following of the Bologna Process. We can note the European Credit Transfer System (ECTS), the Diploma supplement, the quality assurance mechanisms, the learning outcomes. These instruments aims to constraint the responsible of the countries members of the Bologna Process to reform their system by integrating the Bologna prescriptions. They are integrated in an "apparatus (in Foucault's sense) of higher education normalization" (see Croché, 2010). The power of the apparatus is due to the fact that prescriptive messages are sent to all the facets of the organization and of management of the higher education establishments.

Listing the entire range of instruments set up to standardize (in general the goal of standardization is to enforce a level of consistency or uniformity to certain practices or operations within the selected environment) higher education in all facets of its functioning would serve little useful purpose. We are interested here only in those instruments related to the organization and the practice of higher education. One of the common characteristics of 
such instruments is that they were presented as trivial, a fact that contributed to hide their potential for change. The majority of them did indeed involve reforms which could be regarded as strictly cosmetic (Croché \& Charlier, 2009). Let us take two examples. The passage on the architecture of studies according to the "3-5-8" model frequently failed to produce any change as regards the exercise of the academic work. In many establishments, the conversion to the ECTS system did not have any effect on academic practices and it was mainly mechanical. A certain number of lecture courses was transformed into an ECTS equivalent. However, conceiving and organizing teaching in the manner considered by ECTS would necessitate a major transformation of practices. It would imply a strong reduction in the activities dedicated to the transfer of knowledge. In this case, as in the case of the "3-5-8" framework (model of studies), observing that the requirements related to the ECTS are often bypassed leads us to the conclusion that the instruments' potential for change is negated. The potential for change of these various instruments can appear only if favorable circumstances allow it, and if actors, therefore, choose to activate them.

\section{The apparatus reaches the heart of the teaching profession}

Among all the standardisation instruments of higher education, learning outcomes undoubtedly have the highest potential for transformation of the university teaching profession, notably because they imply to predict the future and then reduce the uncertainty and the risks. Here, we will analyse only the standardization implied in teaching by the learning outcomes, not forgetting that the standardization is taking place in many different dimensions of modern higher education including research performance and management process.

The definition of learning outcomes is given for the first time in the European prescriptive texts, in particular, in the ECTS Users' Guide 2004. The learning outcomes are, thus, defined as:

"statements of what a learner is expected to know, understand and/or be able to demonstrate after a completion of a process of learning" (European Commission, 2004: 44).

In 2015, the European Commission defined the learning outcomes as

"statements of what the individual knows, understands and is able to do on completion of a learning process" (European Commission, 2015: 72).

This explicit presentation of the results that the learner can expect at the end of his or her personal learning pathway is common in countries where the financing of studies is either totally or partially provided by the students. However, defining learning outcomes goes against all traditions in countries where this financing is provided by the community. Today, in countries where the volume of public funding of education depends directly on the market share of each establishment, the learning outcomes model is applied on a 
voluntary basis. In 2015, 32 european countries members of the Bologna process steering and encouraging the use of learning outcomes in curriculum developpement, while 14 encourage learning outcomes through guidelines or recommendations. The importance of learning outcomes in programme development has grown (European Commission/EACEA/Eurydice (2015: 71).

Souto Lopez (2015) presents a history on the introduction of learning outcomes to the piloting system of the European higher education area's establishments and notably in Belgium. He shows three expected effects of the learning outcomes: at the international level, they could support the recognition of qualifications; at the national level, they were useful within the framework of the quality assurance mechanisms; at the local level, they made it possible to identify the best adapted teaching practices and methods. It goes without saying that this identification of the "good practices" goes hand in hand with measures intended to both support such practices and to discourage less effective practices.

The document Guide for Busy Academics. Using Learning Outcomes to Design a Course and Assess Learning is a good illustration of the new method. It explains more precisely "the learning that teachers are seeking to promote" at the University of Bristol in United Kingdom (see University of Bristol, s.d.). The curriculum and its "intended learning outcomes", the teaching methods used, the resources to support learning, and the assessment tasks and criteria for evaluating learning - need to be "aligned" to each other and facilitate the achievement of the intended learning outcomes. The document underlines the main steps in the alignment process:

“1) Defining the intended learning outcomes (which determine the teaching and curriculum objectives - the steps we take to achieve the learning outcomes.)

2) Choosing teaching/learning activities likely to lead to, help and encourage students to attain these intended learning outcomes.

3) Engaging students in these learning activities through the teaching process.

4) Assessing what students have learnt using methods that enable students to demonstrate the intended learning and, in the case of formative assessment, giving feedback to help students improve their learning.

5) Evaluating/judging how well students match learning intentions: a process that is guided through explicit and manageable criteria.

6) Awarding marks/grades in line with these judgements".

The potential for the influence of learning outcomes on professors' practices will be achieved only if standardised measurements are carried out on a scale sufficient to facilitate reliable comparisons. The project "Assessing Higher Education Learning Outcomes" 
(AHELO) of the OECD was launched at this end in 2010. This project was an answer to a request addressed by the Ministers of Education from the OECD countries at a meeting in Athens in 2006. In January 2008, assembled at an informal meeting in Tokyo, the Ministers specified their request and encouraged the OECD to set up one "PISA for the superior" (OECD, 2008). A feasibility study, focused on the studies of economics and civil engineering, was completed in 2012 in 17 countries. The next objective is to carry out tests in other sectors in all the OECD countries after 2016 (OECD, 2014). The modus operandi here is very similar here to that used in the PISA investigation or to the open method of coordination. Data are made public and accessible by national decision makers. They allow for a swift comparison of the performance of various systems, which encourages the persons in charge of the least efficient systems to adopt measures to improve their output. If it is still too early to affirm that the AHELO project will achieve a dynamic of this kind, based on the observation of the effects produced by PISA, one may assume this will occur.

\section{The willingness to put an end to the organised anarchy by means of instruments}

After this brief examination of some standardisation instruments of higher education, let us return to the theories presented in the introduction. According to these theories, universities are seen as "organised anarchies" (in general, these terms suggests that organizations tend to formulate objectives in responses to their activities rather than in advance, that organizational members do not fully comprehend the workings of the organization, and that their involvement in organizational activites is fluid and unpredictable) or "loosely coupled systems", in which one can find "unclear technologies". The efforts both of the European Commission and the OECD seem to aim at correcting the characteristics of the university that these concepts underline. For Friedberg and Musselin (1989), an organised anarchy is the product of rational strategies used by professors to avoid any quantitative evaluation of the research and teaching activities at the university. Thus, anarchy is only presumed and it does not concern all aspects of university work. The question of the coexistence of both supposed organisational anarchy and the rationality of scientific work can be answered by Thompson (1967). He shows that organisations search at the same time for rationality and indetermination: the technical core constitutes a closed system, where uncertainty is excluded, whereas the institutional level maintains openness, thus giving the appearance of anarchy. The concept of "loosely coupled system" makes it possible to explain this double nature. Both rationality and indetermination are necessary for the effective performance of the organisation - here the university. The only possible manner in which to preserve rationality and indetermination at the same time is by locating them at different places and by preventing cross-contamination.

The research carried out, which is summed up in the underlined statements above, mentioned that the organisation is not homogeneous and the actors involved seek to 
preserve the heterogeneity of the segments that constitute it. The decoupling dimension is also addressed by Meyer and Rowan (1977: 58). They consider that educational establishments must try to reconcile incompatibilities between institutional and technical pressures. They do this by decoupling the formal structures from activities in order to maintain the "ceremonial conformity". Decoupling is "a logout deliberated between the organisational structures which reinforce legitimacy and the organisational practices which are regarded by the organisation as being most efficient".

In the universities, the rationality core is easy to identify and is designed around research and administration methods of scientific proof. Meanwhile, the sources of uncertainty are diverse and each one of them is likely to cause or maintain the strategies of segmentation or decoupling. They relate to the political and societal expectations as regards the university, the labour market's reaction to graduates' skills, the effectiveness of the used teaching methods, the relevance of the research protocols, etc.

The outcomes-based model in higher education highlights both the learning outcomes and the incentives provided to researchers to focus their work on concrete applications; it seeks to generate each one of these uncertainties by an explicit procedure. The project assumes the distinction between teaching and research activities and also the clarification by control indicators of the effectiveness of both types of activities. With regard to teaching activities, piloting by learning outcomes seeks to provide to decision makers and operators the means for measuring teaching efficiency.

"Measures of learning outcomes also hold important promises for higher education faculties and leaders in providing evidence-based diagnosis tools on the strengths and weaknesses of their courses and programmes to be used as part of their quality improvement efforts." (Tremblay et al., 2012: 56)

It is not sure that the project's promises carried through the learning outcomes could be held. The learning outcomes aim to create a consistency between the objectives of teaching, the evaluations, and the teaching methods. In short, it is an instrument that seeks to make the teaching result more predictable and even more programmable (see Legendre, 2012 ; Brancaleone \& O'Brien, 2011). It does this by proposing a specific managing system of uncertainty that defines the manner in which the learner will react to the stimuli which are presented to him. On the one hand, the instrument - here the learning outcomes - is underlined by the recognition of what is obvious. The obvious, in this case, is the fact that it is up to each student to develop his competences. On the other hand, it provides means for measuring the effectiveness of the various methods used to lead the student to the Intended Learning Outcomes (Biggs \& Tang, 2007). The unpredictable character of the learner's reactions ceases, thus, to be a factor of uncertainty. It becomes simply one of the variables that the learning outcomes have the authority to manage. 
The learning outcomes can also contribute to disarm the argument of the irreducibility of the teacher's work, put forward, in particular, by authors denouncing "academic capitalism". "Learning, and research require reflection, engagement, collaboration, trialand-error, processing, practice; all of which take time" (Walker, 2009: 68). Higher education ceases to be one of those "professions with prudential practice", defined by Champy (2009) as professions where it is impossible to precisely envisage the result of the actions initiated. In this case, the choice of whom does not imply the application of an unquestionable scientific framework. The choice results then from the professional's conviction, and from his approval of the risk, which is a risk in respect of which he may be held to account.

All the instruments (ECTS, quality assurance mechanisms, learning outcomes, etc.), which concern the academic profession, have implications for university management in Europe and conduct to think the academic profession and the university management as a couple of issue. They were created in order to divest the universities of the characteristics that led some analysts to approximate such establishments to organised anarchies, with weak interdependence, using unclear technologies. Such instruments lead to extreme specialisation of tasks, which, thereby, triggers changes in collegial management. Management is entrusted to managers who may be strangers to the university world. The organisation of education is delegated to technicians of applied pedagogy, who may come from private offices of engineering as it is the case notably in Denmark and in other Nordic countries (see Kalpazidou-Schmidt \& Langberg, 2007). Research is entrusted to specialised researchers, assisted by professionals in the drafting of file requests for funding. Teaching becomes the responsibility of professors specialised in pedagogic animation, surrounded by technicians who guide them (as it is more and more the case in Belgium since the adoption of the learning outcomes approach (see Souto Lopez, 2015)). In this way, each segment of the organisation utilises those technologies considered to be the most efficient by the professionals of that particular segment. Each one is, thus, controlled in the most rational way. The question of interdependence then arises in renewed terms: the specialisation of tasks and techniques reduces the interferences between the segments, but generates a deep interdependence between all the segments and activities conducted within the same segment.

In Europe, few countries are engaged in the specialization of the four spheres presented above. Examples of commitments to carry out radical reforms in one or the other spheres are easy to find. The countries undergoing these reforms are then presented by the pilots of the Bologna Process as examples of good practices which must inspire all the others, in Europe but also in other World regions and especially in Africa (Charlier, Croché \& Panait 2016). 
If all the instruments presented in this paper have implications in European higher education, they also have (or could have) implications in other World regions which took the European reforms as model. For example, the learning outcomes approach is integrated in the Tuning (Tuning Educational Structures in Europe) project which was first launched in Europe and which aims to contribute to the transparency of curricula as well as the development of learning outcomes and quality assurance. This project was used also as a model by countries from South America, Russia, United states and Africa which have adapted it to their own needs (Croché \& Charlier, 2012). Then, now, it is impossible to think reforms engaged in Europe without considering their worldwide integration. Instruments such as the creation of the AHELO, a global cross-countries initiatives, help to think Higher Education reforms on a worldwide basis.

\section{References}

European Commission/EACEA/Eurydice (2015). The European Higher Education Area in 2015: Bologna Process Implementation Report. Luxembourg: Publications Office of the European Union.

Biggs, J., \& Tang, C. (2007). Teaching for Quality learning at University. Maidenhead: McGraw-Hill and Open University Press.

Brancaleone, D., \& O'Brien, S. (2011). Educational Commodification and the (economic) sign value of Learning Outcomes. British Journal of Sociology of Education, 32(4), 501-519.

Champy, F. (2009). La sociologie des professions. Paris: PUF.

Charlier J-É., Croché, S., \& Panait, O. (2016). Inter-regional higher education arena: the transposition of European instruments in Africa, in: Robertson, S.L., Olds, K., Dale, R., Dang, Q.A. (Ed.) Global Regionalisms and Higher Education. Northampton: Edward Elgar Publishing, 85-102.

Cohen, M.D., \& March, J.G. (1974). Leadership and Ambiguity: The American College President. New York: McGraw Hill Book Company.

Cohen, M.D., March, J.G., \& Olsen, J.P. (1972). A Garbage Can Model of Organizational Choice. Administrative Science Quarterly, 17(1), 1-25.

Croché, S. (2010). Le pilotage du processus de Bologne. Louvain-la-Neuve: AcademiaBruylant.

Croché, S., \& Charlier, J.É. (dir.) (2009). Le processus de Bologne et ses effets. Éducation et sociétés, 33. Louvain-la-Neuve : De Boeck.

Croché, S., \& Charlier, J.É. (2012). Normative influence of the Bologna Process on Frenchspeaking African universities. Globalisation, Societies and Education, 10(4), 457-472.

Derouet, J.-L., \& Normand, R. (2012). Les nouvelles épreuves d'Homo Academicus. Revisiter la condition universitaire dans une société de la connaissance, in : Charlier, J.E., Croché, S., \& Leclercq, B. (dir.) Contrôler la qualité dans l'enseignement supérieur. Louvain-La-Neuve : Academia. 
European Commission (2004). ECTS Users' Guide. European Credit Transfer and Accumulation System and the Diploma Supplement. Brussels: OPOCE.

European Commission (2015). ECTS Users' Guide. Luxembourg: OPOCE.

Evans, L., \& Nixon, J. (Dir.) (2015). Academic Identities in Higher Education. Changing European Landscape. London : Bloomsbury Academic.

Friedberg, E., \& Musselin, C. (1989). En quête d'universités. Paris: L'Harmattan.

Kalpazidou-Schmidt, K.E., \& Langberg, K. (2007). Academic Autonomy in a Rapidly Changing Higher Education Framework : Academia on the Procrustean Bed?. European Education, 39(4), 80-94.

Legendre, F. (2012). Processus de Bologne dans l'enseignement supérieur hongrois : représentations et pratiques enseignantes. Carrefours de l'éducation, 34, 211-226.

Lucas, L. (2014). Academic resistance to quality assurance processes in higher education in the UK. Policy and Society, 33, 215-224.

Meyer, J.W., \& Rowan, B. (1977). Institutionalized organizations: Formal structure as myth and ceremony. American Journal of Sociology, 80, 340-363.

Normand, R. (2015). The challenges of the French 'homo academicus': Modernization, identities and the sense of justice, in : Evans, L., \& Nixon, J. (dir.) Academic Identities in Higher Education: The Changing European Landscape. New-York : Bloomsbury Academic, part III (chapter 9).

OECD (2008). Réunion informelle des ministres de l'éducation des pays de l'OCDE sur l'évaluation des résultats de l'enseignement supérieur, Tokyo, 11-12 janvier. Available from http://www.oecd.org/document/20/0,3343,en_2649 $33723 \quad 39926612$ _1_1_1_1,00.html

OECD (2014). Testing student and university performance globally: OECD's AHELO. Available from http://www.oecd.org/edu/skills-beyondschool/testingstudentanduniversityperformancegloballyoecdsahelo.html

Orton, J.D., \& Weick, K.E. (1990). Loosely Coupled Systems: A Reconceptualization. Academy of Management Review, 15(2), 203-223.

Souto Lopez, M. (2015). Resserrer le dispositif européen de l'enseignement supérieur par les acquis d'apprentissage. Thèse de doctorat en sociologie. Mons-Lyon : Université catholique de Louvain-École normale supérieure de Lyon.

Thompson, J.D. (1967). Organizations in action: Social sciences bases of administrative theory. New-York: Mc Graw-Hill.

Tremblay, K., Lalancette, D., \& Rosevaere, D. (2012). AHELO. Feasibility Study Report. Volume 1 Design and Implementation. Paris: OECD.

University of Bristol (s.d.). Guide for Busy Academics. Using Learning Outcomes to Design a Course and Assess Learning. Available at www.bristol.ac.uk/esu/intendedlearningoutcomes/busyacademics.rtf

Walker, J. (2009). Time as the fourth dimension in the Globalization of Higher Education. The Journal of Higher Education, 50(5), 483-509.

Weick, K.E. (1976). Educational organizations as loosely coupled systems. Administrative Science Quarterly, 21, 1-19. 